\title{
РОЗВИТОК ГОТЕЛЬНИХ МЕРЕЖ В УКРАЇНІ ТА ШЛЯХИ ÏХ РОЗШИРЕННЯ В МІСТІ ОДЕСА ТА ОДЕСЬКОЇ ОБЛАСТІ
}

\author{
DEVELOPMENT OF HOTEL CHAINS IN UKRAINE \\ AND WAYS TO EXPAND THEM IN THE CITY OF ODESSA \\ AND THE ODESSA REGION
}

\author{
Тітомир Людмила Анатоліївна \\ кандидат технічних наук, доцент, \\ Одеський національний технологічний університет \\ ORCID: https://orcid.org/0000-0003-3701-2972 \\ Жовтяк Каріна Олександрівна \\ асистент, \\ Одеський національний технологічний університет \\ ORCID: https://orcid.org/0000-0001-7665-2396 \\ Савенко Анастасія Андріївна \\ асистент, \\ Одеський національний технологічний університет \\ ORCID: https://orcid.org/0000-0002-4643-9401
}

\author{
Titomir Lyudmila, Zhovtyak Karina, Savenko Anastasia \\ Odessa National Technological University
}

\begin{abstract}
Стаття присвячена актуальним питанням у пошуку новітніх шляхів у розширенні готельних мереж, які стосуються сучасних готелів та вітчизняних у місті Одеса включаючи іії область. Розвиток готельних мереж в місті Одеса і області не заважаючи на особливість економіко-географрічного розташування, розвинену інфраструктуру як культурну, так і транспортну, а також стрімку відвідуваність туристами за останні роки, готельні мережі міста та області на сьогоднішній день знаходиться на низькому рівні, порівняно із іншими великими містами. Це знеособлює загальний розвиток індустрії гостинності та сореру обслуговування, втрачається престижність та пізнаваність готелів, зростають конкурентні переваги у інших міст України, викуповуються земельні ділянки в центральній частині міста, в курортних та рекреаційних зонах під забудову багатоквартирних споруд, торгівельних підприємств, тим самим забравши місця для створення майбутніх, нових готельних мереж в Одесі та області. Така ситуація негативно позначиться і на нові майбутні робочі місця для жителів міста, що сприятиме лише їхньому виїзду для пошуку нових робочих місць за кордоном. При цьому місто не отримає майбутніх прибутків на оподаткування за рахунок готельних надходжень, що негативно сприятиме економіці та розвитку міста у культурних, розважальних місцях. Перспективний напрям розвитку ринку готельних послуг становить формування національних та регіональних (вітчизняних) готельних мереж, які об'єднані в торговельні марки зі стабільно високим рівнем обслуговування. Найбільш затребувані два сегменти готельного господарства. Перший сегмент - це готелі економкласу (дві-три зірки), цільову аудиторію яких становлять іноземні та вітчизняні гості, що подорожують із культурно-пізнавальними, лікувально-оздоровчими цілями та для відпочинку або розваг. Другий сегмент - фешенебельні готелі (чотири-п'ять зірок), розташовані у центральній частині міста. Їхню цільову аудиторію становлять гості із діловими цілями по вирішенню власних робочих питань. Основні вимоги до таких готелів полягають у наданні гостям розширеного переліку бізнес-послуг. Таким чином пошук нових шляхів для створення готельних мереж національних, регіональних (вітчизняних) відновить динаміку у індустрії ссрери гостинності міста Одеса включаючи і її область.
\end{abstract}

Ключові слова: готельна мережа, національність, концепція, готельний бренд, сегмент ринку готельних послуг.

Статья посвящена актуальным вопросам поиска новейших путей в расширении гостиничных сетей, касающихся современных гостиниц и отечественных в городе Одесса включая и ее область. Развитие гостиничных сетей в городе Одесса и области не мешая особенностям экономико-географического расположения, развитой инфраструктуре как культурной, так и транспортной, а также стремительной посещаемости туристами 
за последние годы, гостиничные сети города и области на сегодняшний день находятся на низком уровне, по сравнению с другими крупными городами. Это обезличивает общее развитие индустрии гостеприимства и сореру обслуживания, теряется престижность и узнаваемость отелей, растут конкурентные преимущества у других городов Украины, выкупаются земельные участки в центральной части города, в курортных и рекреационных зонах под застройку многоквартирных сооружений, торговых предприятий, тем самым забрав места для создание будущих новых гостиничных сетей в Одессе и области. Такая ситуация негативно отразится и на новых будущих рабочих местах для жителей города, что будет способствовать только их выезду для поиска новых рабочих мест за границей. При этом город не получит будущих налогооблагаемых прибылей за счет гостиничных поступлений, что негативно будет способствовать экономике и развитию города в культурных, развлекательных местах. Перспективное направление развития рынка гостиничных услуг составляет фрормирование национальных и региональных (отечественных) гостиничных сетей, объединенных в торговые марки со стабильно высоким уровнем обслуживания. Наиболее востребованы два сегмента гостиничного хозяйства. Первый сегмент - это отели экономкласса (две-три звезды), целевую аудиторию которых составляют иностранные и отечественные гости, путешествующие с культурно-познавательными, лечебно-оздоровительными целями и для отдыха или развлечений. Второй сегмент - фешенебельные отели (четыре-пять звезд), расположенные в центральной части города. Их целевую аудиторию составляют гости с деловыми целями по решению собственных рабочих вопросов. Основные требования к таким гостиницам заключаются в предоставлении гостям расширенного перечня бизнес-услуг. Таким образом, поиск новых путей для создания гостиничных сетей национальных, региональных (отечественных) возобновит динамику в индустрии сореры гостеприимства города Одесса включая и ее область.

Ключевые слова: гостиничная сеть, национальность, концепция, гостиничный бренд, сегмент рынка гостиничных услуг.

The article is devoted to topical issues in the search for new ways to expand hotel chains, which relate to modern hotels and domestic in the city of Odessa, including its region. The development of hotel chains in the city of Odessa and the region, despite the peculiarities of economic and geographical location, developed infrastructure, both cultural and transport, as well as rapid tourist attendance in recent years, hotel chains in the city and region today is low compared to other large cities. This depersonalizes the general development of the hospitality industry and the service sector, the prestige and recognition of hotels is lost, competitive advantages are growing in other cities of Ukraine, land plots are being bought in the central part of the city, in resort and recreational areas for apartment buildings. creation of future, new hotel chains in Odessa and the region. This situation will have a negative impact on new future jobs for city residents, which will only facilitate their departure to find new jobs abroad. At the same time, the city will not receive future tax revenues from hotel revenues, which will negatively contribute to the economy and development of the city in cultural and entertainment places. A promising direction in the development of the hotel services market is the formation of national and regional (domestic) hotel chains, which are combined into brands with a consistently high level of service. The most popular are two segments of the hotel industry. The first segment is economy class hotels (two or three stars), the target audience of which are foreign and domestic guests traveling for cultural, educational and health purposes and for recreation or entertainment. The second segment - luxury hotels (four or five stars), located in the central part of the city. Their target audience is guests with business goals to solve their own work issues. The main requirements for such hotels are to provide guests with an expanded range of business services. Thus, the search for new ways to create hotel chains of national, regional (domestic) will restore the dynamics in the hospitality industry of the city of Odessa, including its region.

Keywords: hotel chain, nationality, concept, hotel brand, hotel services market segment.

Постановка проблеми. Готельний бізнес це найбільш затребувана послуга у туристичній індустрії гостинності, який втілює всі побажання гостя, створює комфрортні умови для проживання, і забезпечує повну безпеку життя кожного гостя. Щоб заповнити ринок готелів, необхідно створювати готельні мережі, котрі вже вправно фрункціонують з великим власним досвідом роботи і пройшли всю процедуру реєстрації кваліфікаційних вимог, та побороли важкі кризові стани ведення бізнесу. За очевидною тенденцією забудови житлових масивів в місті Одеса, можна прогнозувати трагічний стан готельних мереж, тому варто про розширення індустрії гостинності вчасності мереж задуматись вже сьогодні.
Аналіз останніх досліджень і публікацій. Дослідженню стану готельного господарства Одеської області включаючи готельні мережі присвячені наукові роботи таких вчених, як О.В. Шикіна [1], С.Г. Нездоймінов, Л.А. Тітомир. Для вирішення постановки проблеми пов'язаної із готельними мережами у місті Одеса та області буде проведено ряд досліджень, які стосуватимуться методів порівняння статистичних даних на фоні вже відомих існуючих готельних мереж. Здійснення аналізу готельних мереж у місті Одеса за методами онлайн-опитування у формі анкетування, за користуванням відповідної літератури зроблено загальний опис. Розглядалися найвідоміші готельні мережі, виявлено 
їх похідні із українськими готельними мережами. Розглянуто новітні тенденції фрункціонування міжнародних та національних готельних мереж на території України. Визначено недоліки та можливі загрози готельних мереж в Україні. Досліджено переваги національних, вітчизняних готельних мереж та визначено шляхи подальшого розвитку готельних мереж у місті Одеса та області.

Формування цілей статті. Мета даного дослідження полягає у актуальності створення нових готельних мереж в місті Одеса, одеської області; здійснення пошуку новітніх шляхів у розширенні мереж за участю світових відомих мереж; проведення аналізу за статистичними методами включаючи експертів із дійсних готельних мереж України.

Виклад основного матеріалу дослідження. Актуальність дослідження готельної мережі обумовлюється сучасністю тенденції розвитку готельного бізнесу у світі та Україні: структура в існуванні ланцюгів зменшує економічні витрати та легко координує процеси в управлінні, позбавляє значних втрат на випадок зменшення туристичного потоку відвідувачів, зберігає контингент працівників та дозволяє контролювати усі готелі під одним ланцюгом значно швидше та ефективніше.

Готельна мережа полягає у об'єднанні декілька готелів в єдину концепцію та стиль, що працює за контрактом на керування готелями. Власник готелів заключає контракт між

Світові готельні мережі

Таблиця 1

\begin{tabular}{|c|c|c|}
\hline Ранг & Мережа готелів & $\begin{array}{c}\text { Кількість } \\
\text { готелів }\end{array}$ \\
\hline 1 & Wyndham по всьому світу & 8,092 \\
\hline 2 & Вибір готелів & 6,429 \\
\hline 3 & Marriott International & 5,974 \\
\hline 4 & InterContinental Hotels Group & 5,070 \\
\hline 5 & Hilton Worldwide & 4,727 \\
\hline 6 & AccorHotels & 4200 \\
\hline 7 & Готелі Best Western & 4,196 \\
\hline 8 & Jin Jiang International & 3,090 \\
\hline 9 & Домашні пансіонати & 3000 \\
\hline 10 & Мотель 6 & 1330 \\
\hline 11 & $\begin{array}{c}\text { Готельний комплекс } \\
\text { Carlson Rezidor }\end{array}$ & 1,112 \\
\hline 12 & Vantage Hospitality & 1,090 \\
\hline 13 & La Quinta Inns та Suites & 889 \\
\hline 14 & Whitebread plc & 700 \\
\hline 15 & Корпорація Hyatt Hotels & 667 \\
\hline
\end{tabular}

компанією яка має дозвіл лише на керування, об'єднавши всі готелі у одну єдину мережу. Завдяки цьому вже з'являється об'єднана система бронювання, централізованість у швидкому та економічному постачанні продукції і матеріалів. Підвищується рівень якості в організації обслуговування, що в результаті, підтримує репутацію готелів та рейтинг на офріційному сайті. Особливою перевагою мережі $€$ економічність у використанні ресурсів для забезпеченості декількох готелів одночасно. Тим самим створивши нову можливість готельним мережам потрапляти на міжнародний туристичний ринок і бути пізнаваним, закріпивши свою назву та концепцію.

На сьогоднішній день існують найвідоміші та найбільші мережі світу, кількість яких з кожним роком лише збільшується, вони наведені в таблиці 1.

Врахувавши розгалуженість та велику кількість відомих мереж світу, можна зробити висновок, що сучасне об'єднання готелів $є$ регульованим та перспективним готельним бізнесом, а ніж управління поодинокими готелями.

Об'єднані готелі в управлінні дають значні переваги власникам та компанії, яка має всі права на керування, тим самим розширення інших мереж $є$ досяжним втіленням для власника. Об'єднання готелів відбувається шляхом укладення контракту на управління між власником підприємства і компанією, головним напрямком діяльності якої $є$ професійне управління готелями на даному сегменті ринку. Компанія, що вступає в управління за контрактом, не отримує ніяких прав на майно підприємства, тим самим компанія страхуючи себе не несе ніякої відповідальності за матеріально-технічну складову готелів.

Готелі, які розташовані у вдалому місті та мають велику місткість із постійною завантаженістю номерів мають великі переваги стати готельною мережею. Мережа шляхом стабільного завантаження номерного фонду гостями дозволяє зменшити витрати на резервування, маркетингові дослідження, рекламу, підготовку кадрів, закупівлю матеріалів, продукцію, сировину для обслуговування. Готельний ланцюг, безумовно, має свої вимоги що прописуються у договорі, які стосуються фрасаду споруди, офрормлення інтер'єру, оснащення всіх служб, однакову систему бронювання, місце розташування, рівень сервісного обслуговування. Інноваційна раціональна ідея, яка народжується в одному кільці готельної мережі, оперативно впроваджується в інші, що приносить одразу ж значні результати. 
Але поширення мережі не може задовільнити усіх різноманітних вимог проживаючих через деяку знеособленість, стандартизованість в обслуговуванні. Саме цей недолік поклав початок тенденції розширення типологізації готелів у мережі: включення в одну мережу готелів різних типів і категорій, що дозволяє задовільнити потреби різних верств населення з різним статком [3].

В Україні за період 2019 по 2021 року готельні мережі розвиваються значно повільніше, оскільки на це впливає значна ситуація із війною на Сході та із масовою пандемією COVID-19 у світі. При такій важкій ситуації інвестори не вкладають значних коштів у розвиток готельної індустрії в Україні та у створення нових готельних мереж, а власники побоюючись кризової ситуації, не готові вкладати власні кошти в щось нове. В супереч усьому деякі власники все ж таки спромоглися розширити власні готельні мережі у 2021 році, під назвами: Radisson Hotel City Center Odesa (90 номерів); Best Western Plus Lviv Market Square (70 номерів); Ibis \& Adagio Kyiv (combo, 265 номерів). А найактивнішими готельними мережами в Україні, котрі спромоглися підтримувати свої готельні мережі на сьогодні є Accor, Mozart Hotel Group, Premier Hotel Odesa, Reikartz Hotel Group, Radisson, InterContinental, Marriott i Hilton.

Крім того, мережі Wyndham i Louvre Hotel Group останнім часом також просували свої бренди і брали участь в тендерах на проекти, в основному через фрранчайзингові пропозиції. Лише мережа готелів «Premier» в місті Одеса має два найпотужніші готелі із великим номерним фондом, а саме: Premier Geneva Hotel (3 «зірки») за місцем розташування знаходиться на вул. Єврейська, 32 та Premier Hotel Odesa (4 «зірки») за адресою вул. Академічна, 32 який відкрився у 2020 році. По всьому світі на сьогодні налічується 16 готельних мереж цієї компанії.

Планується відкриття у 2022 році Premier Hotel Slavutych який стане четвертим готелем мережі Premier в Києві. Повністю оновлений сучасний комплекс на Русанівській набережній, лівого берега Дніпра. Готель буде налічувати близько 272 номерів, кілька барів, ресторанів і фрітнес-центр з тренажерними залами та масажними кабінетами. Особливу увагу буде приділено конференц-зоні. Великий залтрансорормер, малий зал і кілька кімнат для переговорів, дозволять проводити декілька заходів одночасно з максимальним комфортом. Готель буде надавати, як і інші готелі цієї мережі, всі необхідні для відпочинку і бізнесу послуги: Room Service, високошвидкісний Wi-Fi, бізнес-центр, транспортне обслуговування, парковка, камера схову, пральня, хімчистка і салон краси. Відмітна особливість в інтер'єрі готелю - це панорамні вікна майже в усіх громадських місцях з чудовими краєвидами на річку Дніпро і її правий берег.

У червні 2021 року мережа готелів Premier відкрила перший міжнародний готель в Угорщині - Premier Hotel Miskolc. Вивчивши можливості та інфрраструктуру готелю, європейська організація сертифрікації готелів присвоїла йому категорію комсрортності 4 «зірки». Невеликий, але затишний готель об'єднав ділову та туристичну спільноти міста Мішкольц. До послуг гостей 24 комфортних номери з видом на місто та традиційний готельний сніданок Premier Buffet Breakfast. Обладнаний конфреренц-зал 3 денним освітленням, парковка, лобі-бар і касре 3 панорамними вікнами: тут є все для роботи та відпочинку. У літній період відкрита вулична тераса. Лідерські позиції готелю вже підтверджені високими рейтингами на популярних платсрормах бронювання.

Перелік готельної мережі Reikartz Hotel Group не перестає дивувати своїм розвитком навіть готельні мережі Marriott i Hilton, оскільки їх перелік по всьому світі у 2021 році становить 40 бізнес-готелів та курортів 3-4 «зірки» в Україні та за кордоном, а також 40 ресторанів таким чином забезпечуючи трудові робочі місця для населення. Україна цієї компанії займає найголовніше та найпопулярніше місце, 36 готелів знаходиться саме тут, а в місті Одеса їх налічується всього два - це Raziotel Маренеро категорії дві зірки та Hotel Milano by Reikartz Collection - чотири зірки. Готельна мережа компанії Mozart Hotel Group налічує 9 готелів по всьому світі, із них 4 готеля фрункціонує в місті Одеса це Hotel Mozart, Hotel Complex Odessa, Hotel Arkadia, Hotel Tsentralnaya.

Ribas Hotels Group почав свій розвиток у сегменті екотуризму: наприкінці серпня 2020 року вже приймали перших відвідувачів та впроваджують інноваційну мережу глемпінгів MANDRA. Перший глемпінг побудували у смт. Затоці і попри низький сезон, він повністю завантажений до кінця листопада. Зараз на території побудовано три глемпи, в яких може жити одночасно 7 людей. Також один великий глемп створений для надання додаткових послуг вільного часу туристів, де можуть поміститися 20-30 людей і один санітарний блок, які виглядають як звичайні ванни кім- 
нати, з душем і умивальником, по одному для кожного глемпу і один загальний для гостей. Таким чином, за підрахунками засновника, його самоокупність відбуватиметься 1-2 роки, зважаючи на сезонність і гості перебувають в глемпінгу з 1 березня до 15 листопада [6].

За підсумками туристичного сезону починаючи з 2019 року Одесу відвідали 3,3 мільйона туристів. 3 них $45 \%$ відсотків складають саме іноземці, $55 \%$ - українці. Надходження туристичного збору в 2019 році склало 11,6 млн. грн., що на 58,9\%, або 4,3 млн. грн., більше, ніж у 2018 році. У 2020 році Одесу відвідали всього 2 мільйони туристів, серед яких іноземців було лише 13\%. Туристичний збір 2020 року склав лише 7,6 млн. грн., що на 4 млн. менше, ніж у 2019 році. При цьому департамент культури і туризму продовжує робити зусилля 3 популяризації Одеси серед іноземних туристів. Для цього, використовували рекламу туристичних можливостей міста Одеси яку розміщували в журналі National Geographic, а також на білбордах в 15 містах України. В ході апаратної наради директор департаменту культури і туризму Одеської міської ради Тетяна Маркова повідомила, що за 10 місяців 2021 року Одесу відвідали більше 3-х мільйонів туристів (3 млн. 317 тис.).

Завантаження готелів в Одесі в серпні 2020 року становила у середньому 68\%. При цьому для багатьох буде несподіваним, що готелі, розташовані в центрі міста, досягли 70\% показника в завантаженні.

Готелі в курортних зонах Аркадія та Ланжерон завантажилися в серпні на 65\%. Про це свідчать дані дослідження готельного ринку Hotel Matrix [7].

Середній тарифр на номер (ADR) в готелях Одеси становив у серпні 2,3 тис. грн. У той же час ADR готелів біля моря в серпні становив 2,9 тис. грн., а прибутковість у розрахунку на номер (RevPAR) - 2 тис. грн. Для готелів в центрі Одеси показники ADR в серпні склали 1,7 тис. грн., RevPAR - 1,1 тис. грн. Дослідження Hotel Matrix зачепило готелі з сукупним номерним фрондом понад 1,7 тис., 3 яких 45\% становили 4-зіркові готелі, 32\% - 5-зіркові. За даними компанії, в Одесі налічується 255 готелів із загальним номерним фрондом 6,572 тис. номерів [8].

Завантаженість готелів в Одесі у 2021 році в січні становило 19\%, зазначено в Hotel Matrix. Таке значне зниження відбувалося під час локдауну, і багато готелів тимчасово закрилися і не працювали в цей період. Середній тариф у готелях Одеси становив 1397 грн., RevPAR відповідно до 370 і 269 грн. Тим самим, більшість готелів констатували свої бюджети зі значними збитками, бо рівень завантаження зі зрозумілих причин скоротився вдвічі, а то й більше. Але ближче до послабленого локдауну готелі відновлювали попередню статистику до 65-75\% завантаженості. А в літній сезон завантаженість у готелях Одеси досягала до 90\%. Таким чином, майбутній шлях розвитку нової готельної мережі в Одесі стає значно реальнішим втіленням та $€$ перспективним розвитком і у інших містах України.

Для кращого розуміння подальшого шляху розвитку готельної мережі Одещини було проведено дослідження за методом онлайн анкетування гостей, які проживали у відомих готельних мережах як: Hotel Mozart, OK Одесса, Hotel Arkadia, Hotel Tsentralnaya, Premier Hotel Odesa. Оскільки саме від задоволення гостей та збільшеного їх потоку залежить можливість розширення готельної мережі в інших місцях.

Відповіді надали 165 осіб із 180 опитаних гостей готелів, не надали 15 осіб, оскільки не вважають для себе розвиток готелів важливим питанням для себе. Відповідь на питання для опитаних складались із двох можливих варіантів «Так або Ні». В анкеті були присутні і відкриті питання. Результати відповідей опитаних гостей готелів зафіксовано та сорормовано у вигляді кругової діаграми і в таблиці 2.

При анкетуванні застосовувалися і відкриті питання, на які гості готельних мереж надавали свою відповідь. Результати даних на попит розширення сектору готельних мереж наведені в таблиці 3.

Як з'ясувалося у ході проведеного дослідження висновки анкетування та опитування проживаючих в готелі та його майбутніх туристів виказали зацікавленість у подальшому розвитку готельних мереж, покращенні інфрраструктури і прибутковості міста та готельного бізнесу в регіоні.

Для подальшого аналізу перспективних шляхів розвитку готельних мереж було застосовано метод експертних оцінок шляхом онлайн-опитування на офріційних сайтах готелів міста Одеси, починаючи із категорій двох до п'яти зіркових готелів, де потрібно було обрати декілька відповідей на власний розсуд або внести власні пропозиції за бажанням. Опитування здійснювалось онлайн на офріційних сайтах готелів міста Одеси, у зв'язку із виникненню епідеміологічною ситуацією та обмеженнями зустрічей у 2020-2021 році. Визначення готелів для опитування експертів 

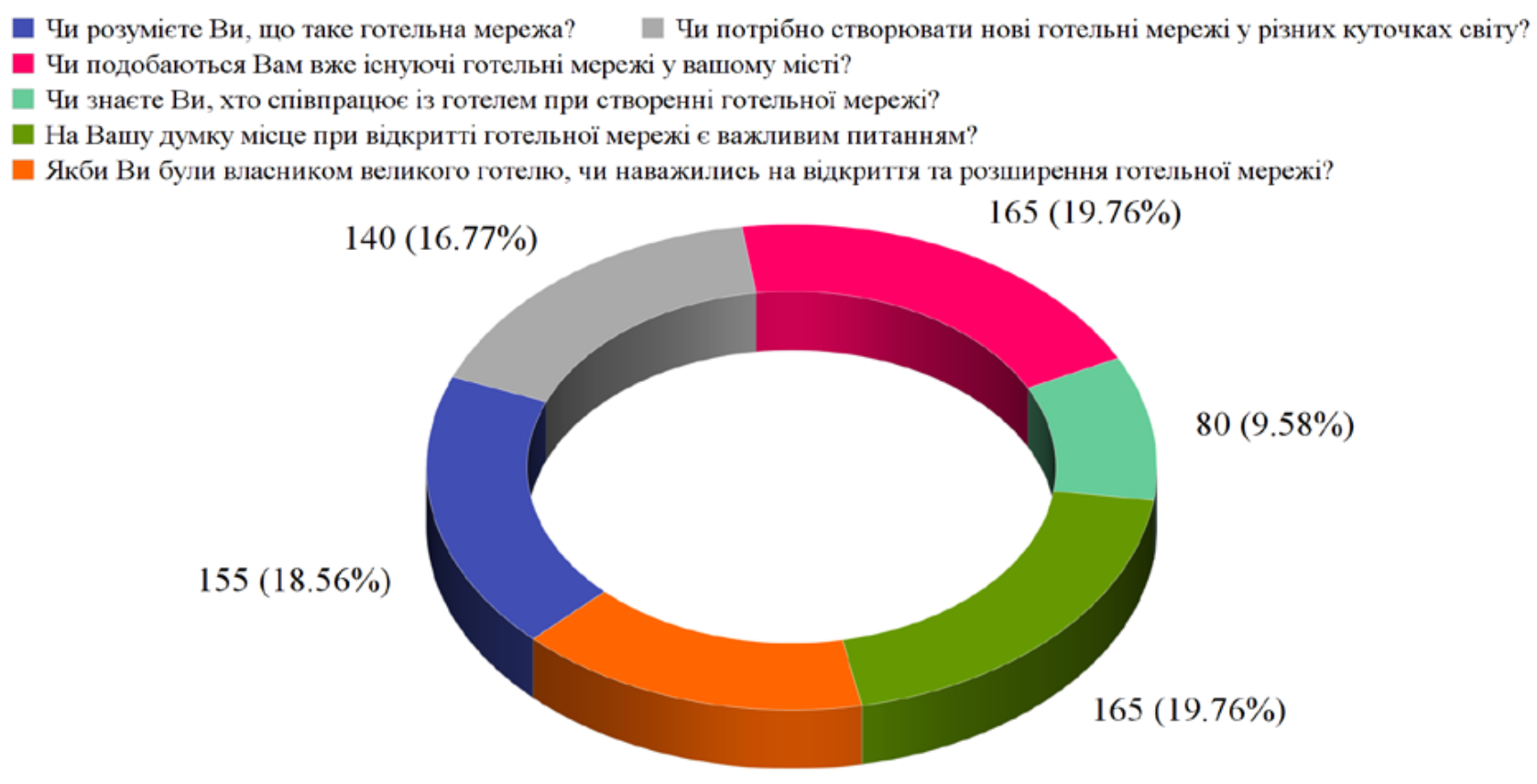

$130(15.57 \%)$

Рис. 1. Кругова діаграма

Джерело: дослідження авторів статmі

відбувалось шляхом привабливості туристами об'єктів готельної інфрраструктури, та за рейтинговими показниками на сайті booking. com, і позитивними відгуками на офріційних сайтах які наведено в таблиці 4.

Експертами були фрахівці із великим досвідом роботи в готельній індустрії понад 10 років, обрано експертів за різними поса- дами починаючи від старшого менеджера до адміністрації готелів вищої ланки. За методом експертних оцінок було визначено тенденції розвитку і шляхи розширення та удосконалення вітчизняних готельних мереж в місті Одеса та Одеської області. Питання для експертів готельної індустрії створювалися за інфрормаційними матеріалами відносно вже

Результати проведеного анкетування гостей готелів

Таблиця 2

\begin{tabular}{|c|l|l|}
\hline № & $\begin{array}{l}\text { Питання для гостей готелів: Hotel Mozart, OK Oдесса, } \\
\text { Hotel Arkadia, Hotel Tsentralnaya, Premier Hotel Odesa }\end{array}$ & $\begin{array}{l}\text { Відповіді опитаних гостей } \\
\text { найвідіших мереж України } \\
\text { міста Одеси }\end{array}$ \\
\hline 1. & Чи розумієте Ви, що таке готельна мережа? & $\begin{array}{l}155-\text { осіб відповіли позитивно } \\
10-\text { осіб відповіли негативно }\end{array}$ \\
\hline 2. & $\begin{array}{l}\text { Чи потрібно створювати нові національні готельні } \\
\text { мережі у різних містах? }\end{array}$ & $\begin{array}{l}140-\text { осіб відповіли так } \\
25-\text { осіб відповіли ні }\end{array}$ \\
\hline 3. & $\begin{array}{l}\text { Чи подобаються Вам вже існуючі готельні мережі } \\
\text { у вашому місті? }\end{array}$ & $\begin{array}{l}165-\text { осіб відповіли } \\
\text { одноголосно, і надали } \\
\text { позитивну відповідь }\end{array}$ \\
\hline 4. & $\begin{array}{l}\text { Чи знаєте Ви, хто співпрацює із готелем при створенні } \\
\text { готельної мережі? }\end{array}$ & $\begin{array}{l}80-\text { осіб відповіли так } \\
85-\text { осіб відповіли ні }\end{array}$ \\
\hline 5. & $\begin{array}{l}\text { На Вашу думку місце при відкритті готельної мережі } \\
\text { є важливим питанням? }\end{array}$ & $\begin{array}{l}165-\text { осіб відповіли так } \\
\text { одноголосно }\end{array}$ \\
\hline 6. & $\begin{array}{l}\text { Якби Ви були власником великого готелю, чи наважились } \\
\text { на відкриття та розширення готельної мережі? }\end{array}$ & $\begin{array}{l}130-\text { осіб відповіли так } \\
35-\text { осіб відповіли ні }\end{array}$ \\
\hline
\end{tabular}


Попит розширення сектору готельних мереж

Таблиця 3

\begin{tabular}{|c|c|c|}
\hline № & $\begin{array}{c}\text { Питання для гостей готелів: Hotel } \\
\text { Mozart, OK Oдесса, Hotel Arkadia, Hotel } \\
\text { Tsentralnaya, Premier Hotel Odesa }\end{array}$ & $\begin{array}{c}\text { Відповіді опитаних гостей найвідоміших } \\
\text { мереж України міста Одеси }\end{array}$ \\
\hline 1. & Які готельні мережі Ви знаєте? & $\begin{array}{l}\text { За результатами у більшості опитаних гостей } \\
\text { у відповідях зафріксовано готельні мережі як } \\
\text { (25\%): } \\
\text { Hilton; Accor; Marriott; Mozart Hotel Group, } \\
\text { Premier; Reikartz; Radisson, InterContinental. }\end{array}$ \\
\hline 2. & $\begin{array}{l}\text { Що є найголовнішим у структурі } \\
\text { готельної мережі? }\end{array}$ & $\begin{array}{l}\text { За результатами опитаних гостей у більшості } \\
\text { відповідях зафріксовано (25\%): } \\
\text { Цілісність; структурованість; надійне } \\
\text { партнерство; фрінансовість; масштабність } \\
\text { готелю; однаковість; підтримка готелів; } \\
\text { співпраця із іншими готелями; кваліфікований } \\
\text { персонал; гості; співпраця із інвесторами. } \\
\end{array}$ \\
\hline 3. & $\begin{array}{l}\text { Яку результативність на Вашу думку дає } \\
\text { відкриття готельної мережі у вашому } \\
\text { місті? }\end{array}$ & $\begin{array}{l}\text { За результатами опитаних гостей у більшості } \\
\text { відповідях зафріксовано (40\%): } \\
\text { Збільшення туристичного потоку іноземних } \\
\text { гостей; розвиток інфрраструктури в місті; } \\
\text { забезпеченість трудовими місцями; підняття } \\
\text { рейтингу як туристичного міста Одеси; } \\
\text { збільшення фрінансового прибутку у місті, } \\
\text { набування гарного стилю міста та області } \\
\end{array}$ \\
\hline 4. & $\begin{array}{l}\text { Який повинен бути фрінансовий капітал } \\
\text { для створення готельної мережі? }\end{array}$ & $\begin{array}{l}\text { Відповіді опитаних гостей різняться, тому } \\
\text { результати зафріксовано саме такі (10\%): } \\
\text { починаючи від 400000\$ і закінчуючи 900000\$. }\end{array}$ \\
\hline
\end{tabular}

Джерело: дослідження авторів статті

Перелік обраних готелів для опитування експертів готельної індустрії

\begin{tabular}{|c|c|c|c|}
\hline № & Назва готелю & Зірковість & Рейтинг \\
\hline 1. & Tsentralnaya Hotel & ** & 8.0 \\
\hline 2. & Arcadia Hotel & 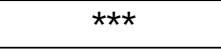 & 8.2 \\
\hline 3. & OK Odessa & 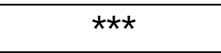 & 8.5 \\
\hline 4. & Black Sea Central & 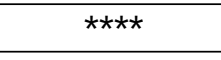 & 8.3 \\
\hline 5. & Radisson Hotel City Centre Odesa & 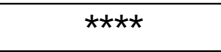 & 8.6 \\
\hline 6. & Alexandrovskiy Hotel & 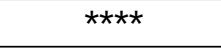 & 9.4 \\
\hline 7. & London Hotel & 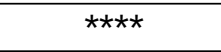 & 9.3 \\
\hline 8. & NEMO Hotel Resort \& Spa & 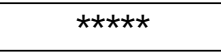 & 9.0 \\
\hline 9. & Hotel Otrada & 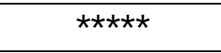 & 9.1 \\
\hline 10. & Premier Hotel Odesa & 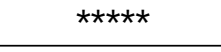 & 9.2 \\
\hline
\end{tabular}

Джерело: [9]

функціональних готельних мереж, і обрано саме ті питання, які $€$ найбільш есрективнішими та важливими для відкриття і удосконалення будь-якої готельної мережі України включаючи місто Одеса і її області. Перелік питань за методом експертних оцінок наведено в таблиці 5.

Відповіді надали 185 респондентів-експертів, які визначилися із найголовнішими шляхами удосконалення діючих готельних мереж, та швидкого сприяння відкриттю нових в місті
Одеса та в області. Візуалізація даних здійснювалась інструментом гістограми. У гістограмі сорормовано 24 питання із відкритими відповідями, для респондентів-експертів. Відображено найнижчий показник «0» і найвищий «10» балів, де респонденти-експерти оцінюють питання за важливістю у сучасному шляху розвитку готельних мереж на Одещині.

Зафріксовано та проаналізовано відповіді респондентів-експертів, за допомогою яких ми дійшли висновку: 
Таблиця 5

\begin{tabular}{|c|c|}
\hline № & Питання для онлайн-опитування фахівців готельного бізнесу \\
\hline 1. & Наявність збільшеної фрінансової подушки в своїх закладах. \\
\hline 2. & Закупівля сучасного, якісного, екологічного обладнання. \\
\hline 3. & Співпраця із маркетинговою компанією. \\
\hline 4. & Підбір кваліфікованого персоналу із знанням 3-х і більше іноземних мов. \\
\hline 5. & Надання безпечного, якісного сервісу кожному гостю без виключення. \\
\hline 6. & Використання централізованої системи бухгалтерського обліку, постачання та збуту. \\
\hline 7. & Великий номерний фронд (понад 200). \\
\hline 8. & Сучасні методи просування готельних послуг в умовах конкурентного середовища. \\
\hline 9. & Пошук закордонних надійних інвесторів. \\
\hline 10. & Чесні стосунки між власником та оператором компанії. \\
\hline 11. & Можливість використання сучасних методів управління якістю готельних послуг. \\
\hline 12. & $\begin{array}{l}\text { Використання спрощеної системи документально між власником та компанією на } \\
\text { законодавчому рівні. }\end{array}$ \\
\hline 13. & Впровадження новітніх ідей креативного характеру в готельну індустрію. \\
\hline 14. & Наявність удосконаленого офріційного сайту та міжнародних систем бронювання. \\
\hline 15. & Розробка стратегії подальшого розвитку підприємств, і здійснення майбутніх прогнозів. \\
\hline 16. & Наявність та перспективи розширення гостевої бази. \\
\hline 17. & Співпраця із туроператорами, туристичними фрірмами, коворкінгами, бізнес центрами. \\
\hline 18. & Користування кредитними системами. \\
\hline 19. & Співпраця із іншими готельними мережами із різним походженням. \\
\hline 20. & Великий штат співробітників у готелі та рівень їх профресіоналізму. \\
\hline 21. & Функціонування всіх служб у готелі, згідно з міжнародними стандартами. \\
\hline 22. & Користування інноваційною системою управління готелем. \\
\hline 23. & Вдале місце розташування із великими туристичними потоками. \\
\hline 24. & Гнучка система тарифрів та програм лояльності. \\
\hline
\end{tabular}

Джерело: дослідження авторів статmі

Шляхи розширення та удосконалення готельних мереж України в Одеській області

12

10

8

6

0

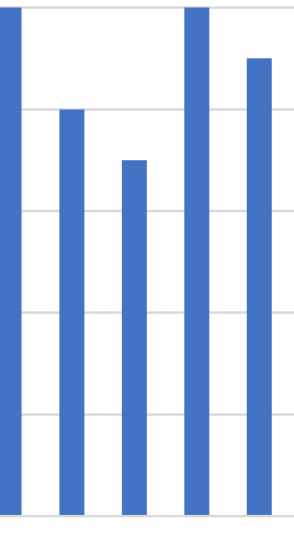

123
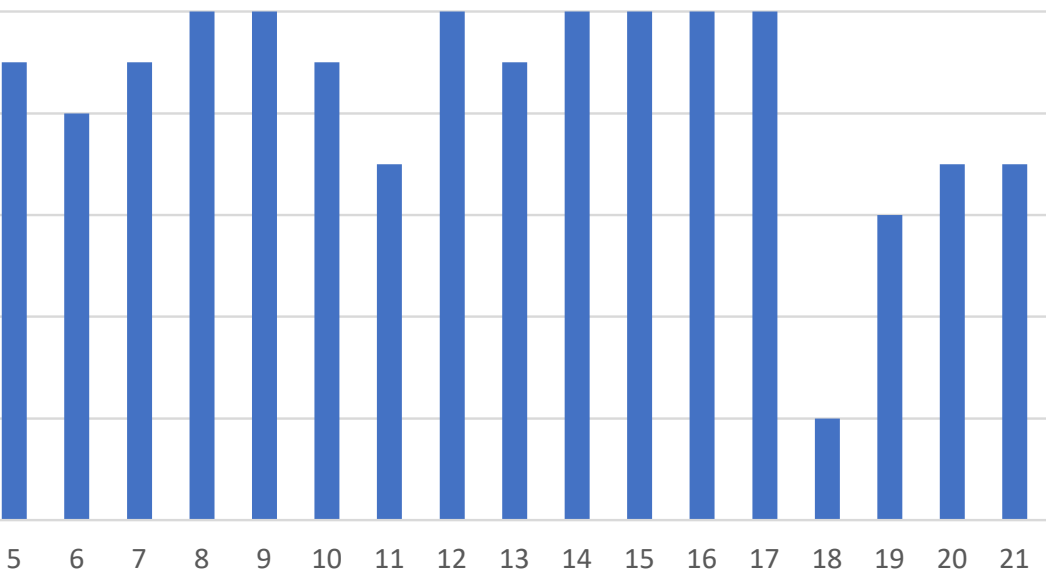

Рис. 2. Гістограма

Джерело: дослідження авторів статті 
- 170 осіб із 185 обрали наявність збільшеної фрінансової подушки, оскільки без неї власники не змогли б відкрити свій власний готельний бізнес;

- 165 осіб із 185 відповіли саме за якісне обладнання схильного до екологічності;

- 130 осіб із 185 вважають, що за допомогою маркетингової компанії готельний бізнес привабить та збільшить кількість гостей у свої заклади;

- 140 осіб із 185 відповіли на те, щоб наймали на роботу лише досвідчений кваліфрікований відповідний персонал;

- 185 осіб одноголосно відповіли, що за якісний безпечний сервіс, адже готельєри 3 кожним днем удосконалюють саме цей напрямок постійно;

- 170 осіб із 185 схильні до централізованої системи бухгалтерського обліку, постачання та збуту;

- 80 осіб із 185 вважають що повинен бути номерний фронд понад 200 для відкриття готельної мережі;

- 185 осіб одноголосно відповіли, що впровадження сучасних систем бронювання та використання інноваційних методів просування і реалізації готельного продукту $є$ необхідним та вигідним рішенням для будь-якого готелю;

- 144 особи із 185 вважають доречним співпрацювати із інвесторами, котрі допоможуть втілити бажане за короткий час;

- 164 осіб із 185 відповіли лише за чесні стосунки між власником та оператором компанії;

- 119 осіб із 185 вважають доречним використання різних методів управління рівнем якості основних та додаткових послуг;

- 185 осіб відповіли одноголосно про використання спрощеної системи документально між власником та компанією на законодавчому рівні;

- 133 осіб із 185 за впровадження новітніх ідей креативного характеру в готельну індустрію, і вважають розвиток ідей зможе привабити нових гостей у свої заклади;

- 185 осіб надали відповідь про наявність удосконаленого офріційного сайту, оскільки вважають, що сайт займає 1 позицію за способом бронювання номерів;

- 185 осіб за розробку стратегій та подальшого розвитку підприємств, і вважають здійснення майбутніх прогнозів $€$ обов'язковим питанням при відкритті готельної мережі;

- 185 осіб вважають наявність клієнтської бази $€$ найголовнішим у розвитку готельної мережі;
- 185 осіб за співпрацю із туроператорами, туристичними фрірмами, коворкінгами, бізнесовими центрами;

- 20 осіб із 185 відповіли лише, що користування кредитними системами необхідно при необхідності;

- 110 осіб із 185 відповіли, що співпраця із іншими готельними мережами із різним походженням $€$ можливістю для підтримки своїх мереж;

- 132 особи із 185 вважають, що великий штат співробітників у готелі зможе задовольнити всі потреби гостей, та покращити сервіс;

- 185 осіб відповіли одноголосно, і вважають, що фрункціонування всіх служб у готелі на вищому рівні це успіх, також готельєри прагнуть у своїх закладах досягти такого результату;

- 185 осіб із 185 вважають користування надійною системою управління готелем призведе до структурованості;

- 185 осіб визначилися лише за вдале місце розташування із великими туристичними потоками, що дасть змогу розвиватися готельній мережі значно швидше;

- 147 осіб із 185 вважають, що гнучка система тарисрів дасть коригування в готельній мережі.

Питання респонденти-експерти із готельної індустрії оцінювали за 10-ти бальною шкалою, де у гістограмі відображено найважливіші шляхи у відкритті нової національної готельної мережі, або на думку експертів вже існуючої для збільшення попиту на них. За результатами респондентів-експертів, які надавали свої пропозиції щодо удосконалення готельних мереж, була визначена можливість і доцільність у розширенні національних готельних мереж та у створюванні нових в місті Одеса і в області.

Висновки. Для готельної мережі головним фрактором в існуванні $\epsilon$ цілісність фрункціонування всіх служб, високий рівень якості послуг, ефективність систем управління всіх готелів, оскільки це являється основою конкурентоспроможності всієї мережі. Для стабільної конкурентоспроможності на ринку готельних послуг в умовах зовнішньої конкуренції готельні мережі використовують сучасні системи управління, змінюючи структуру та організаційні методи для її реалізації. Так, наприклад, готелі мережі «Mozart Hotel Group» та «Premier», у яких раніше була фрункціональна структура управління, і за час приєднання нових готелів комплексно в інших місцях за період 2019-2021 рр., їм вдалося створити лінійно-фрункціональну структуру, яка допомогла налагодити всі служби в контр- 
олі та звітності. Впровадження нової структури управління покращила якість сервісного обслуговування туристів, швидкість комплексного надання послуг та ефрективність виконання управлінських рішень у всіх ланках готельної мережі. Результативність та позитивність здійснених досліджень з залученням експертів дає можливість вирішення безліч питань відносно відкриттю нової готельної мережі, удосконалення вже існуючої за рахунок приєднання нових готельних комплексів 3 індивідуальною тематикою і категорією.
Готелі міста Одеси і області мають можливість проаналізувати свою конкурентоспроможність, визначитися із сильними та слабкими сторонами для того, щоб покращити роботу у всіх службах. Удосконалити сервісне обслуговування, безпеку, систему управління, стандарти, впровадити новітні технології, можливо змінити стратегію або наважитись на відкриття нової готельної мережі під своїм брендом, знайти нові шляхи для приваблення туристичного потоку у свої заклади для нового розвитку готелю.

\section{СПИСОК ВИКОРИСТАНИХ ДЖЕРЕЛ:}

1. Шикіна О.В. Дослідження фрункціонування міжнародної готельної мережі «Marriott». Приазовський економічний вісник. 2019. № 6(17). С. 222-227.

2. Головне управління статистики в Одеській області. Колективні засоби розміщування (2011-2020). Туризм. URL: http://www.od.ukrstat.gov.ua/

3. Басюк О.В. Аналіз світового досвіду фрункціонування готельних ланцюгів. Глобальні та національні проблеми економіки. 2015. № 5. URL: http://global-national.in.ua/issue-5-2015/13-vipusk-5-traven-2015-r/746basyuk-o-v-analiz-svitovogo-dosvidu-funktsionuvannya-gotelnikh-lantsyugiv

4. Матеріали IX Всеукраїнської науково-практичної конференції «Інноваційні технології в готельно-ресторанному бізнесі», 19-20 травня 2020 р. Київ : НУХТ, 2020. 305 с.

5. Найбільші готельні мережі світу. URL: https://uk.history-hub.com/naibilshi-gotelni-merezhi-svitu

6. Розвиток глемпінгу на Одещині. URL: https://omore.city/articles/105701/glamurnij-kemping-mandra-v-zatoci

7. Завантаження готелів в місті Одеса. URL: https://www.marketing-ua.com/zavantazhennya-goteliv-v-odesiv-serpni-2020-sklala-68-doslidzhennyal

8. Низька завантаженість та фрінансові втрати. URL: https://fakty.com.ua/ua/ukraine/20200916-nyzkazavantazhenist-ta-finansovi-vtraty-yak-odeski-goteli-perezhyly-koronakryzu/

9. Пошукова глобальна система готелів. URL: https://www.booking.com

\section{REFERENCES:}

1. Shikina O.V. (2019) Research of functioning of the international hotel network "Marriott". Priazovsky economic bulletin, no. 6(17), pp. 222-227.

2. Main Department of Statistics in the Odessa region. Collective placement tools (2011-2020). Tourism. Available at: http://www.od.ukrstat.gov.ua/

3. Basyuk O.V. (2015) Analysis of world experience in the operation of hotel chains. Journal of Global and National Economic Problems, no. 5. Available at: http://global-national.in.ua/issue-5-2015/13-vipusk-5-traven-2015r/746-basyuk-ov-analiz-svitovogo-dosvidu-funktsionuvannya-gotelnikh- lantsyugiv

4. Proceedings of the IX All-Ukrainian scientific-practical conference "Innovative technologies in the hotel and restaurant business", May 19-20. Kyiv: NUHT, 2020. 305 p.

5. The largest hotel chains in the world. Available at: https://uk.history-hub.com/naibilshi-gotelni-merezhi-svitu

6. Development of glamping in the Odessa region. Available at: https://omore.city/articles/105701/glamurnijkemping-mandra-v-zatoci

7. Loading hotels in Odessa. Available at: https://www.marketing-ua.com/zavantazhennya-goteliv-v-odesi-vserpni-2020-sklala-68-doslidzhennyal

8. Low workload and financial losses. Available at: https://fakty.com.ua/ua/ukraine/20200916-nyzka-zavantazhenist-ta-finansovi-vtraty-yak-odeski-goteli-perezhyly-koronakryzu/

9. Search global system of hotels. Available at: https://www.booking.com 